\title{
Bubble column application on purification of biogas and production of nano-calcium carbonate in continuous process
}

\author{
Yukh Ihsana, Putu Adhi Rama, Ratri Puspita, Sugeng Winardi", Tantular Nurtono \\ Department of Chemical Engineering, Faculty of Industrial Engineering, Institut Teknologi Sepuluh Nopember (ITS), Kampus ITS Sukolilo, \\ Surabaya 60111, Indonesia \\ * Corresponding author: swinardi@chem-eng.its.ac.id
}

\section{Article history}

Received 5 April 2019

Revised 25 May 2019

Accepted 19 August 2019

Published Online 15 June 2020

\section{Graphical abstract}

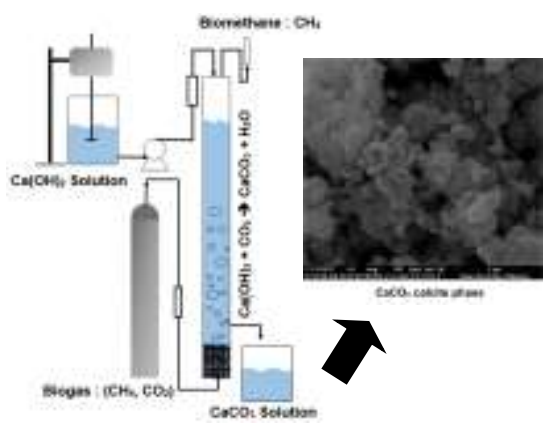

\begin{abstract}
Purification of biogas by removing carbon dioxide content has been developed to increase its calorific value. The $\mathrm{CO}_{2}$ contained in biogas was absorbed by contacting $\mathrm{Ca}(\mathrm{OH})_{2}$ solution and $\mathrm{CO}_{2}$ in the bubble column to produce high purity of biogas and generated precipitated calcium carbonate (PCC) simultaneously. Two sources of $\mathrm{CO}_{2}$ were used in this work, which were $\mathrm{CO}_{2}$ contained in biogas and pure $\mathrm{CO}_{2}$. Pure $\mathrm{CO}_{2}$ was used as a benchmark in this study to show the effect of the presence of methane contained in biogas on the absorption process. The investigation was done in a continuous process. The results showed that the highest absorption of $\mathrm{CO}_{2}$ was obtained in biogas at $79.34 \%$. PCC with calcite phases was successfully formed in $225-270 \mathrm{~nm}$. Rhombohedral calcite phase was formed by the use of pure $\mathrm{CO}_{2}$ and biogas as a source of $\mathrm{CO}_{2}$. The use of $\mathrm{CO}_{2}$ contained in biogas and pure $\mathrm{CO}_{2}$ in the absorption process did not have an effect on the crystalline phase and morphology of calcite formed. Several factors that significantly affected the absorption of $\mathrm{CO}_{2}$ were gas flow rate, absorbent flow rate, $\mathrm{CO}_{2}$ concentration in the gas inlet, and the initial liquid level in the bubble column.
\end{abstract}

Keywords: Biogas, absorption, precipitated calcium carbonate

(C) 2020 Penerbit UTM Press. All rights reserved

\section{INTRODUCTION}

Biogas is one of the promising alternative energies to reduce dependency on fossil fuels. Typically, biogas consists of methane $\left(\mathrm{CH}_{4}, 50-70 \%\right)$, carbon dioxide $\left(\mathrm{CO}_{2}, 30-40 \%\right)$, hydrogen $\left(\mathrm{H}_{2}, 5-10\right.$ $\%)$, nitrogen $\left(\mathrm{N}_{2}, 1-2 \%\right)$, water $\left(\mathrm{H}_{2} \mathrm{O}, 0.3 \%\right)$, and hydrogen sulfide $\left(\mathrm{H}_{2} \mathrm{~S}\right)$ (Mamun et al., 2015). The presence of a high concentration of $\mathrm{CO}_{2}$ in biogas causes corrosion of the reactor due to the formation of carbonic acid. In addition, it can reduce the heating value of the biogas. Therefore, upgrading biogas into biomethane by $\mathrm{CO}_{2}$ absorption is important to increase biogas quality and heating value. Water scrubbing is a proven, simple, and universal technology for $\mathrm{CO}_{2}$ removal in various flow rates. This technology can also reduce $\mathrm{H}_{2} \mathrm{~S}$ in high quantities, but this process consumes large amounts of water. Chemical and physical absorption is preferably used for medium or large-scale process, so it is more suitable applied in industry or pilot scale biogas reactor installations in rural areas (Niesner et al., 2013). Chemical absorption with amine-based absorbents such as monoethanolamine (MEA) and diethanolamine (DEA) has been developed for 70 years as an absorbent for acidic gases such as $\mathrm{H}_{2} \mathrm{~S}$ and $\mathrm{CO}_{2}$ (Han et al., 2011). This process consists of three stageswhich are absorbing $\mathrm{CO}_{2}$ gas in the absorbent, releasing $\mathrm{CO}_{2}$ trapped in absorbent, and $\mathrm{CO}_{2}$ liquefaction which is a costly stage. All processes mentioned above only focusing on $\mathrm{CO}_{2}$ capturing and storing. Converting $\mathrm{CO}_{2}$ into a valuable product can be an alternative process. This process is more economical than other $\mathrm{CO}_{2}$ absorption because it does not require additional $\mathrm{CO}_{2}$ liquefaction costs.

Process of $\mathrm{CO}_{2}$ absorption with $\mathrm{Ca}(\mathrm{OH})_{2}$ solution followed by the formation of precipitated calcium carbonate (PCC) is an advantages alternative process. PCC is known as a product that has many uses in industry. Previous work has investigated the possibility of PCC production with high purity and narrow particle distribution size by reacting $\mathrm{CO}_{2}$ and calcium extracted from blast furnace (slag). However, this process needs more pretreatment to extract calcium from slag and results in co-precipitation of magnesium carbonate more than PCC (De Crom et al., 2015). From this method, it is possible to produce PCC and purify biogas simultaneously by reacting carbon dioxide contained in biogas and $\mathrm{Ca}(\mathrm{OH})_{2}$ solution. Even though this process is a classic method, it may be adopted and modified for application in a small scale of biogas production. There is rare literature available in small-scale of biogas upgrading systems. Some advantages of using this process include $\mathrm{CaO}$ as an inexpensive raw material, a simple reaction process, and precipitated calcium carbonate which is the result of the process can add a commercial value of the biogas purification process. In addition, regeneration and disposing of a residual solution are friendly to the environment if it is carried out in the long term. Although this process has limitations of raw materials derived from nature, a lot of research on $\mathrm{CaO}$ regeneration of $\mathrm{CaCO}_{3}$ has developed by thermal dissociation process commonly referred to as Ca-Looping (Han et al., 2011).

In the previous work (Ihsana et al., 2017), the biogas absorption process in semi-batch using a bubble column has been successfully 
used to purify biogas and synthesize nanoparticle precipitated calcium carbonate simultaneously. $\mathrm{CaCO}_{3}$ has been successfully formed in calcite phase. Previously, the use of absorbent concentration is based on its solubility. $\mathrm{Ca}(\mathrm{OH})_{2}$ solution is fed in the bubble column until it fully reacts. From this semi-batch process, it has been found that the use of a perforated plate with a hole diameter of $0.5 \mathrm{~mm}$ gives greater absorption compared to that with $1 \mathrm{~mm}$ diameter hole. This work was carried out in continuous absorption to determine the maximum performance of $\mathrm{CO}_{2}$ absorption on different operating conditions. The effect of absorbent concentration, gas flow rate, solution level, and absorbent flow rate on $\mathrm{CO}_{2}$ absorption were investigated. In addition, the optimum conditions for $\mathrm{CO}_{2}$ capture were reported.

\section{EXPERIMENTAL}

\section{Materials}

Materials used in this work consisted of QUALI-TECH CHEM technical grade $\mathrm{Ca}(\mathrm{OH})_{2} 99 \%$ Pure, $\mathrm{CO}_{2} 99.9 \%$ (v/v), and aquadest. Biogas used in this research was from the installation of the reactor pilot plant in the rural area. Cow manure was used as a substrate to produce biogas. This biogas contained $67.8 \%$ of methane $\left(\mathrm{CH}_{4}\right), 32.2$ $\%$ of carbon dioxide $\left(\mathrm{CO}_{2}\right)$, and other components such as hydrogen sulfide $\left(\mathrm{H}_{2} \mathrm{~S}\right)$, and water $\left(\mathrm{H}_{2} \mathrm{O}\right)$ after desulfurization using zeolite and dehydration using water trap. As shown in Fig. 1, the bubble column used in biogas purification was made from acrylic. It has an inside diameter of $7 \mathrm{~cm}$ with a thickness of $0.5 \mathrm{~cm}$ and a height of $100 \mathrm{~cm}$. The biogas from the gas cylinder was supplied through a distributor consisting of a perforated plate and glass beads. This perforated plate has a hole diameter of $0.5 \mathrm{~mm}$ with an active area of $0.332 \mathrm{~cm}^{2}$. This perforated plate was used to produce bubbles which were contacted with $\mathrm{Ca}(\mathrm{OH})_{2}$ solution. At the bottom of the bubble column, there were glass beads that had an average diameter of $0.3 \mathrm{~cm} . \mathrm{Ca}(\mathrm{OH})_{2}$ solution was fed countercurrent into the bubble column. Before entering the bubble column, $\mathrm{Ca}(\mathrm{OH})_{2}$ solution was stirred in a feed tank using a stirrer. Biogas flow was controlled by the flowmeter. The exit gas would be collected using the Tedlar bag for analyzing biogas content using the gas chromatograph.

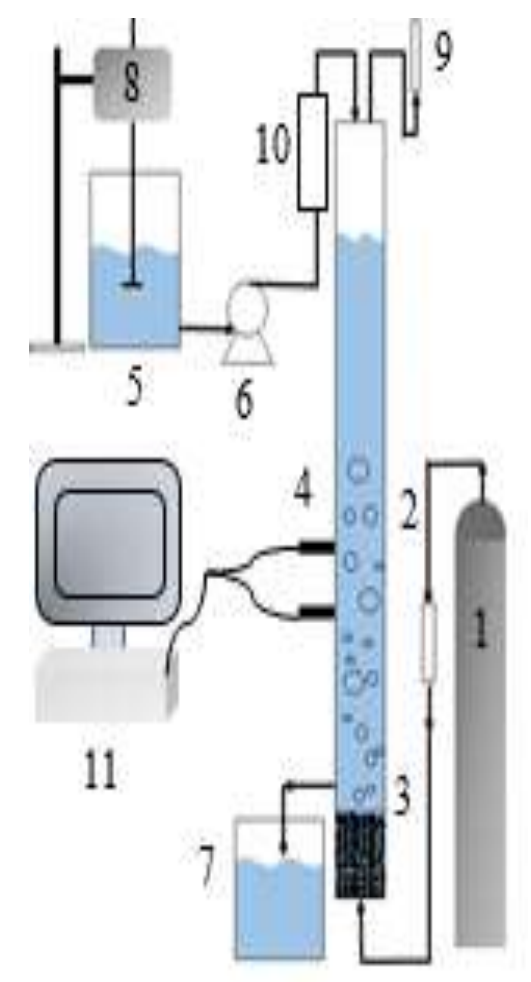

1. Cylindrical biogas tank

2. Flowmeter

3. Distributor

4. Bubble Column

5. Feed Tank

6. Diaphragm Pump

7. PCC tank

8. Stirrer Unit

9. Gas flowmeter

10. Flowmeter of $\mathrm{Ca}(\mathrm{OH})_{2}$

11. Conductivity meter

Fig. 1 Schematic purification experiment apparatus in a continuous process

\section{Synthesis of Precipitated Calcium Carbonate (PCC)}

The absorbent concentration used in this process was varied of $1.5,2$, and 2.5 times of $\mathrm{Ca}(\mathrm{OH})_{2}$ solubility at $30{ }^{\circ} \mathrm{C}$. This concentration was varied at $2.38,3.068$, and 3.82 gram/liter, respectively. Gas flow rates used were $0.5,0.6,0.7,0.8$, and 0.9 liter/min. The total volume of $\mathrm{Ca}(\mathrm{OH})_{2}$ solution used in this study was 10 liters. The $\mathrm{Ca}(\mathrm{OH})_{2}$ flow rate used was varied at 200, 250, 300, 350 , and $400 \mathrm{~mL} / \mathrm{min}$. The initial liquid level was varied at 50,65 , and $80 \mathrm{~cm}$ to determine the performance of $\mathrm{CO}_{2}$ absorption in a solution of $\mathrm{Ca}(\mathrm{OH})_{2}$ at a certain height. Two conductometer probes were installed at a certain height to find out the reaction runs at a different liquid level. In this absorption process, two sources of $\mathrm{CO}_{2}$ were used. They were pure $\mathrm{CO}_{2}$ and biogas. Pure $\mathrm{CO}_{2}$ was used to know the influence of other gases contained in biogas on the absorption process.

The solution of $\mathrm{Ca}(\mathrm{OH})_{2}$ was prepared by dissolving 23.8 grams of $\mathrm{Ca}(\mathrm{OH})_{2}$ in 1 liter of water. This solution was stirred using a magnetic stirrer at a constant speed of $450 \mathrm{rpm}$ with the solution temperature of $60{ }^{\circ} \mathrm{C}$. $\mathrm{Ca}(\mathrm{OH})_{2}$ solution was fed into the feed tank with an addition of 9 liters of water and then was flowed by diaphragm pump into the bubble column to a certain height. The flow rates of inlet and outlet solutions were kept constant. At the same time, biogas was fed at the bottom bubble column. The determination of $\mathrm{CO}_{2}$ absorbed was done by different treatment between pure $\mathrm{CO}_{2}$ and biogas. In pure $\mathrm{CO}_{2}$, the absorption was determined by changes in the flow rate of the outgoing gas while the biogas absorption was determined from the exit gas sampling which was analyzed by gas chromatography. Gas sampling was done when gas hold up was constant. The gas flow rate was stopped when the solution in the feed tank had run out completely. Then, the sample from the reactor was collected, filtered, and cooled for 12 hours. Calcium carbonate was dried at $60{ }^{\circ} \mathrm{C}$ for 12 hours before calculating its weight and performing its characterization. The content of $\mathrm{CH}_{4}$ and $\mathrm{CO}_{2}$ in biogas was analyzed using gas chromatography (Shimadzu GC-2010 Plus Kyoto, Japan) with Thermal conductivity detector (TCD). The type of $\mathrm{CaCO}_{3}$ crystals, morphology phase, and purity of $\mathrm{Ca}$ were analyzed using X-ray powder diffraction (XRD), SEM (Scanning Electron Microscopy), and XRF (X-ray fluorescence), respectively. The average diameter of $300 \mathrm{CaCO}_{3}$ particles was calculated using image analysis software.

\section{RESULTS AND DISCUSSION}

\section{Effect of Gas Flow Rate on Absorption}

Effect of gas flow rate on absorption has been observed at concentration, $\mathrm{Ca}(\mathrm{OH})_{2}$ flow rate, and the initial liquid level of 3.06 gram/liter, $200 \mathrm{~mL} /$ minute, and $50 \mathrm{~cm}$, respectively. In general, Fig. 2 shows the reduction in absorption of $\mathrm{CO}_{2}$ in biogas and pure $\mathrm{CO}_{2}$ when the gas flow rate is increased. The greater gas flow rate, the faster the $\mathrm{pH}$ required to go to neutral. The $\mathrm{pH}$ changes in the carbonation solution have been studied in previous work and report that the greater gas flow rate used make the $\mathrm{pH}$ change to neutral faster. The neutral $\mathrm{pH}$ will decrease the performance of the absorbent to absorb $\mathrm{CO}_{2}$. When $\mathrm{pH}$ value is more than 10 , more $\mathrm{PCC}$ is converted. This is because carbonate ions are dominant at this high $\mathrm{pH}$. Conversely, when the $\mathrm{pH}$ is low, precipitation will be decreased with the presence of $\mathrm{H}_{2} \mathrm{CO}_{3}$ in the absence of bicarbonate and carbonate ions. At neutral $\mathrm{pH}$, bicarbonate ions are formed and it is difficult to form carbonates with divalent ions. Hence, it is difficult to form precipitation of $\mathrm{CaCO}_{3}$ (Bang et al., 2011).

Compared to the absorption of biogas, the absorption of pure $\mathrm{CO}_{2}$ is not as significant as in biogas. Based on film theory, increasing the inlet concentration of $\mathrm{CO}_{2}$ allows more $\mathrm{CO}_{2}$ molecules to travel the bulk gas to the gas-liquid interface, resulting in higher absorption efficiency. However, gas with the hight content of $\mathrm{CO}_{2}$ in pure $\mathrm{CO}_{2}$ at the same flow rate, the absorbent mole ratio to carbon dioxide decreased, leading to a reduction in efficiency of absorption (Yincheng et al., 2011). This is also seen in Table 1. The use of pure $\mathrm{CO}_{2}$ is not worthy if the ratio of $\mathrm{Ca}(\mathrm{OH})_{2} / \mathrm{CO}_{2}$ is smaller than 1 . This could have a significant effect if the concentration of $\mathrm{Ca}(\mathrm{OH})_{2}$ is large. 


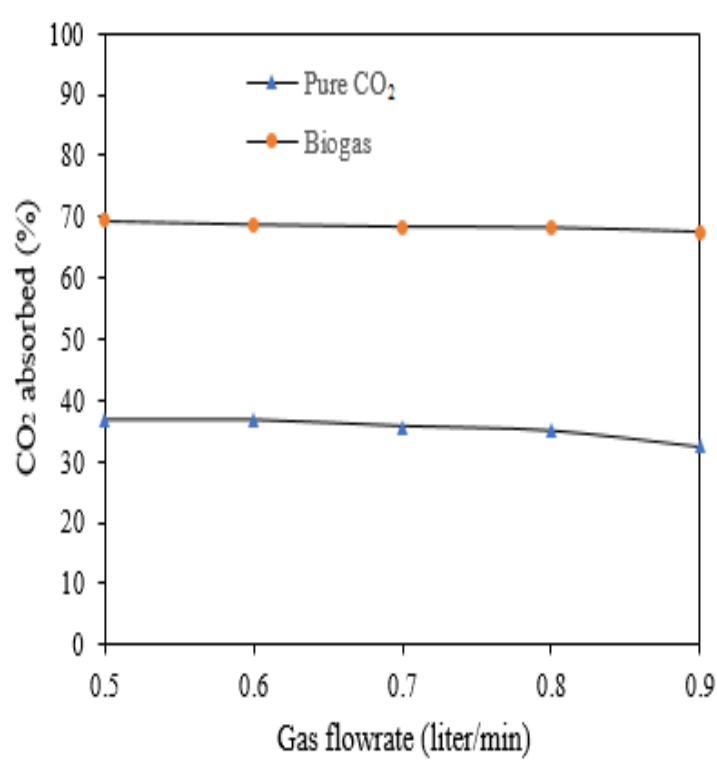

Fig. 2 Effect of gas flow rate on $\mathrm{CO}_{2}$ absorption.

Based on Table 1, the highest $\mathrm{CO}_{2}$ absorption is obtained from the lowest gas flow rate in both biogas and pure $\mathrm{CO}_{2}$. However, the mole ratio of $\mathrm{Ca}(\mathrm{OH})_{2} / \mathrm{CO}_{2}$ in biogas is higher than pure $\mathrm{CO}_{2}$. It causes higher $\mathrm{CO}_{2}$ absorption in biogas. Based on stoichiometry, every 1 mole of $\mathrm{Ca}(\mathrm{OH})_{2}$ requires 1 mole of $\mathrm{CO}_{2}$ to react completely. At least, to obtain maximum absorption, $\mathrm{Ca}(\mathrm{OH})_{2}$ must be greater than $\mathrm{CO}_{2}$ entering with a mole ratio of $\mathrm{Ca}(\mathrm{OH})_{2} / \mathrm{CO}_{2}$ greater than 1 but it depends on the efficiency of the column design and operating condition. There are several studies that have found that to get $\mathrm{CO}_{2}$ absorption of around $90 \%$, the mole ratio of absorbent and $\mathrm{CO}_{2}$ used should be equal to 4.43 . It was based on research conducted using a spray column using $\mathrm{NaOH}$ as an absorbent and it was contacted with $15 \% \mathrm{CO}_{2}$ inlet content (Yincheng et al., 2011). Table 1 presents the mole ratio of $\mathrm{Ca}(\mathrm{OH})_{2} / \mathrm{CO}_{2}$ on $\mathrm{CO}_{2}$ absorption.

Table 1 Mole ratio of $\mathrm{Ca}(\mathrm{OH})_{2} / \mathrm{CO}_{2}$ on $\mathrm{CO}_{2}$ absorption.

\begin{tabular}{ccccc}
\hline $\begin{array}{c}\text { Gas flow } \\
\text { rate } \\
\text { (liter/minute) }\end{array}$ & $\begin{array}{c}{ }^{*} \mathrm{Mole} \text { ratio } \\
\mathrm{Ca}(\mathrm{OH})_{2} / \mathrm{CO}_{2}\end{array}$ & $\begin{array}{c}{ }^{*} \mathrm{CO}_{2} \\
\text { absorbed } \\
(\%)\end{array}$ & $\begin{array}{c}\text { Mole ratio } \\
\mathrm{Ca}(\mathrm{OH})_{2} / \mathrm{CO}_{2}\end{array}$ & $\begin{array}{c}\mathrm{CO}_{2} \text { absorbed } \\
(\%)\end{array}$ \\
\hline 0.5 & 0.37 & 36.37 & 1.15 & 69.35 \\
0.6 & 0.31 & 36.66 & 0.96 & 68.74 \\
0.7 & 0.26 & 35.72 & 0.82 & 68.36 \\
0.8 & 0.23 & 35 & 0.72 & 68.21 \\
0.9 & 0.21 & 32.54 & 0.64 & 67.43 \\
\hline *Pure $\mathrm{CO}_{2}$ & & & &
\end{tabular}

\section{Effect of $\mathrm{Ca}(\mathrm{OH})_{2}$ Flow Rate on Absorption}

As shown in Fig. 3, to determine the effect of $\mathrm{Ca}(\mathrm{OH})_{2}$ flow rate, it is varied by $200,250,300,350$, and $400 \mathrm{~mL} / \mathrm{min}$. Meanwhile, the concentration of $\mathrm{Ca}(\mathrm{OH})_{2}$, gas flow rate, and the level of the solution were kept constant at 3.06 gram/liter, 0.7 liters $/ \mathrm{min}$, and $50 \mathrm{~cm}$, respectively. The absorption process in pure $\mathrm{CO}_{2}$ and biogas shows that in the presence of an increased $\mathrm{Ca}(\mathrm{OH})_{2}$, flow rate will increase the amount of $\mathrm{CO}_{2}$ absorbed. In a study that has been done by Liu et al. (2015), $\mathrm{CO}_{2}$ absorption will increase when the $\mathrm{Ca}(\mathrm{OH})_{2}$ flow rate is increased. By increasing the flow rate of $\mathrm{Ca}(\mathrm{OH})_{2}$, this will increase interface friction phase and decrease the resistance to the liquid film, thus causing diffusion of $\mathrm{CO}_{2}$ and the reaction rate to increase. The highest $\mathrm{CO}_{2}$ absorption is produced at the absorbent flow rate of 400 $\mathrm{mL} / \mathrm{min}$

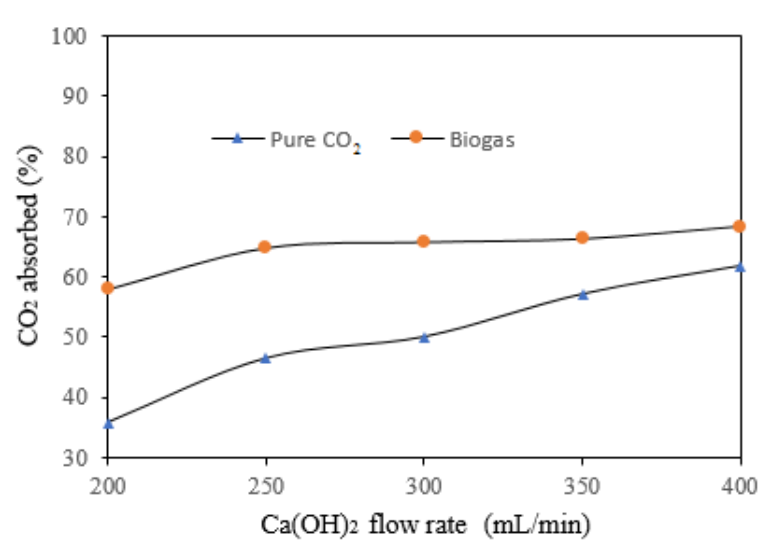

Fig. 3 Effect of $\mathrm{Ca}(\mathrm{OH})_{2}$ flow rate on $\mathrm{CO}_{2}$ absorption.

As seen in Table 2, the absorption of $\mathrm{CO}_{2}$ and the mole ratio of $\mathrm{Ca}(\mathrm{OH})_{2} / \mathrm{CO}_{2}$ at $400 \mathrm{~mL} / \mathrm{min}$ in pure $\mathrm{CO}_{2}$ are $61.85 \%$ and 0.52 , respectively. With the same concentration of $\mathrm{Ca}(\mathrm{OH})_{2}$, the increased absorbent flow rate gives a greater mole ratio. The absorbent requirement will be greater if the gas inlet has lower $\mathrm{CO}_{2}$ content. Based on the study of $\mathrm{CO}_{2}$ absorption in the spray column and $\mathrm{NaOH}$ as absorbent, to get absorption efficiency around $90 \%$, the mole ratio of absorbent and $\mathrm{CO}_{2}$ used should be at 4.43 (Yincheng et al., 2011). This is due to the $\mathrm{CO}_{2}$ content of the inlet used that is equal to $15 \%$. Increasing $\mathrm{CO}_{2}$ absorption by increasing the absorbent flow rate is considered to be an efficient option to avoid using high absorbent concentrations (Tippayawong et al., 2010). This is be useful for reducing the regeneration load of the absorbents used and reducing the use of $\mathrm{CaO}$ as raw materials. The presence of $\mathrm{CH}_{4}$ as an inert in biogas followed by increasing absorbent flow rate provide a large mole ratio of $\mathrm{Ca}(\mathrm{OH})_{2} / \mathrm{CO}_{2}$. In biogas, at a $\mathrm{Ca}(\mathrm{OH})_{2}$ flow rate of 400 $\mathrm{mL} / \mathrm{minute}$ has a mole ratio of 1.64 with the $\mathrm{CO}_{2}$ absorption of 68.35 $\%$. The mole ratio of $\mathrm{Ca}(\mathrm{OH})_{2} / \mathrm{CO}_{2}$ will be greater if the gas inlet has a lower $\mathrm{CO}_{2}$ content. While in the gas inlet with high $\mathrm{CO}_{2}$ content as in pure $\mathrm{CO}_{2}$ has a smaller ratio with smaller absorption. This means that in a gas that has a high inlet concentration, the mole ratio of $\mathrm{Ca}(\mathrm{OH})_{2} / \mathrm{CO}_{2}$ needed to get the same output with the absorption of biogas must be greater. This is also in accordance with research conducted by Guido et al. (2017). The minimum ratio of liquid/gas (L/G) needed to get the same output at the same flow rate will be greater when the gas concentration increases. In a continuous process with a low absorbent flow rate of $200 \mathrm{~mL} / \mathrm{min}$, the mole ratio $\mathrm{Ca}(\mathrm{OH})_{2} / \mathrm{CO}_{2}$ are 0.26 and 0.82 in pure $\mathrm{CO}_{2}$ and biogas with the $\mathrm{CO}_{2}$ absorption of $35.71 \%$, and $68.36 \%$, respectively. On the other hand, at $\mathrm{Ca}(\mathrm{OH})_{2}$ flow rate of $400 \mathrm{~mL} /$ minute, the absorption is not noteworthy where the absorptions are $61.86 \%$ and $79.34 \%$ in pure $\mathrm{CO}_{2}$ and biogas, respectively. Noted that at the same flow rate of 400 $\mathrm{mL} /$ minute, the mole ratio of $\mathrm{Ca}(\mathrm{OH})_{2}$ and $\mathrm{CO}_{2}$ in biogas are almost 2 times that of pure $\mathrm{CO}_{2}$. This means that in the absorption process with a low $\mathrm{CO}_{2}$ inlet gas content, it must have a larger mole ratio $\mathrm{Ca}(\mathrm{OH})_{2} / \mathrm{CO}_{2}$ by increasing the absorbent flow rate to obtain higher absorption.

Table 2 The mole ratio of $\mathrm{Ca}(\mathrm{OH})_{2} / \mathrm{CO}_{2}$ on pure $\mathrm{CO}_{2}$ and biogas absorption in a continuous process.

\begin{tabular}{|c|c|c|c|c|}
\hline $\begin{array}{l}\text { Absorbent } \\
\text { flow rate } \\
\text { (mL/minute) }\end{array}$ & $\begin{array}{l}{ }^{*} \text { Mole ratio } \\
\mathrm{Ca}(\mathrm{OH})_{2} / \mathrm{CO}_{2}\end{array}$ & $\begin{array}{c}{ }^{*} \mathrm{CO}_{2} \\
\text { absorbed } \\
(\%)\end{array}$ & $\begin{array}{c}\text { Mole ratio } \\
\mathrm{Ca}(\mathrm{OH})_{2} / \mathrm{CO}_{2}\end{array}$ & $\begin{array}{c}\mathrm{CO}_{2} \text { absorbed } \\
(\%)\end{array}$ \\
\hline 200 & 0.26 & 35.71 & 0.82 & 08.30 \\
\hline 250 & 0.33 & 46.42 & 1.02 & $I 0 .<0$ \\
\hline 300 & 0.39 & 50 & 1.23 & ד. ד. \\
\hline 350 & 0.46 & 57.14 & 1.43 & , u. \\
\hline 400 & 0.52 & 61.86 & 1.64 & \\
\hline
\end{tabular}

* Pure $\mathrm{CO}_{2}$ 


\section{Effect of $\mathrm{Ca}(\mathrm{OH})_{2}$ concentration on $\mathrm{CO}_{2}$ absorption}

Fig. 4 shows that $\mathrm{CO}_{2}$ absorption increases when $\mathrm{Ca}(\mathrm{OH})_{2}$ concentration increases. However, the absorption of $\mathrm{CO}_{2}$ in the biogas is greater than that of the pure carbon dioxide absorption. It is apparent that the use of absorbents above the solubility shows greater absorption. However, the trend of increasing $\mathrm{CO}_{2}$ absorption is not obvious with an increase in concentration. The reaction occurring between $\mathrm{Ca}(\mathrm{OH})_{2}$ and $\mathrm{CO}_{2}$ is an instant reaction type, with gas resistance as a control. $\mathrm{Ca}(\mathrm{OH})_{2}$ concentration must be excessive to obtain high absorption. When the concentration of the absorbent solution used is low, the reaction occurs in the liquid body. Whereas, if the absorbent concentration is high, the reaction will move from the liquid body to the interface between the liquid and the gas. So, it will increase the gas absorption because the gas resistance becomes small. However, the reaction will tend to remain at the interface when the absorbent concentration is constantly raised (Hayashi et al., 1975). At certain concentration limits, the absorption does not occur noticeably due to the increase in the concentration of the solution. Increasing $\mathrm{CO}_{2}$ absorption by increasing absorbent flow rate becomes a more efficient option than using high absorbent concentrations. This will be useful for reducing the regeneration load of the absorbents used.

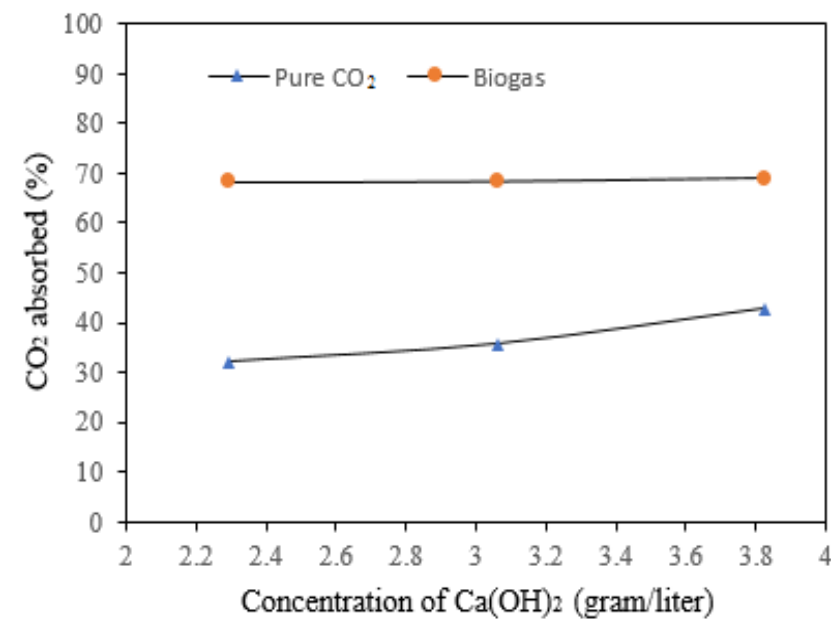

Fig. 4 Effect of $\mathrm{Ca}(\mathrm{OH})_{2}$ concentration on $\mathrm{CO}_{2}$ absorption.

\section{Effect of initial $\mathrm{Ca}(\mathrm{OH})_{2}$ solution level on $\mathrm{CO}_{2}$ absorption}

As shown in Fig. 5, the initial level of $\mathrm{Ca}(\mathrm{OH})_{2}$ solution is varied, i.e. 50,65 , and $80 \mathrm{~cm}$. The figure shows that the higher absorption is obtained on the higher initial liquid level. This trend is due to the higher initial liquid level in the bubble column resulting in longer residence time and increased interfacial area. The greater the interfacial area, the more gas that contacts to the liquid so that absorption occurs maximally. The highest $\mathrm{CO}_{2}$ absorption is produced at $80 \mathrm{~cm}$ solution level in the continuous biogas system. In this study, the percentage of $\mathrm{CO}_{2}$ absorbed in biogas were twice of pure $\mathrm{CO}_{2}$. This is due to the presence of other gas mixtures in biogas such as $\mathrm{CH}_{4}$ and $\mathrm{H}_{2} \mathrm{~S}$. The other gas mixture in biogas serves as an inert. The large content and solubility of methane $(0.00175$ grams gas in 1 gram of water) inhibit the $\mathrm{CO}_{2}$ to react with $\mathrm{Ca}(\mathrm{OH})_{2}$ solution. Even though methane does not react and affect the carbonation process, it affects the absorption time. In addition, $\mathrm{CO}_{2}$ is an acidic gas and polar so the chemical reaction will occur with $\mathrm{Ca}(\mathrm{OH})_{2}$ solution. Conversely, the structure of tetrahedral-shaped methane gas makes methane gas non-polar so it cannot react with $\mathrm{Ca}(\mathrm{OH})_{2}$ (Rashed et al., 2015). Other study also reported that the presence of inert can increase the hold-up gas in $\mathrm{Ca}(\mathrm{OH})_{2}$ solution so that the gas contact time in the solution is longer (Van Baten et al., 2004). Increasing gas hold up causes more gas to be trapped in the solution so that it will increase the contact time between liquid and gas.

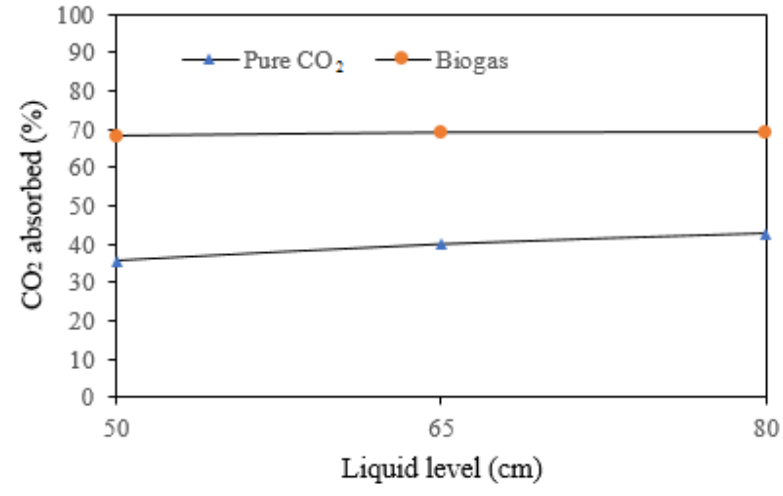

Fig. 5 Effect of initial $\mathrm{Ca}(\mathrm{OH})_{2}$ solution level on $\mathrm{CO}_{2}$ absorption.

To study of the performance of a reaction that runs in a bubble column at a certain liquid level, conductivity measurements are carried out at two points as seen in Fig. 6 The first point is located at a height of $25 \mathrm{~cm}$, while the second point at the liquid level of $50 \mathrm{~cm}$, $65 \mathrm{~cm}$, and $80 \mathrm{~cm}$ is located at a height of $45 \mathrm{~cm}, 60 \mathrm{~cm}$, and $75 \mathrm{~cm}$, respectively. As seen in Fig. 6, there are two stages of the mechanism in the process of forming PCC. The first stage runs for about 20 minutes where there is still high conductivity. While the second stage is characterized by a decrease in conductivity to a constant. In the first stage, the $\mathrm{pH}$ is still around the range $12-10$, while in the second stage, the $\mathrm{pH}$ is ranged from $<10$ to neutral. According to Bang et al.( 2011), $\mathrm{CO}_{2}$ in certain $\mathrm{pH}$ variations has different forms, namely $\mathrm{CO}_{3}{ }^{2-}$ , $\mathrm{HCO}^{3-}$, and $\mathrm{H}_{2} \mathrm{CO}_{3}$ at $\mathrm{pH}>10,6-10$, and $<6$, respectively. At the beginning of the reaction, calcium ions from a solution of $\mathrm{Ca}(\mathrm{OH})_{2}$ react with $\mathrm{CO}_{3}{ }^{2-}$ forming $\mathrm{CaCO}_{3}$ at a high $\mathrm{pH}$ because of the availability of hydroxide ions which can maintain the $\mathrm{pH}$ level in solution. When $\mathrm{pH}$ decreases, the presence of $\mathrm{CO}_{3}{ }^{2-}$ decreases and forms $\mathrm{HCO}^{3-}$, which reduces the precipitation formation. At this stage, it is also called the hatched region (HR), which is identified by a steep $\mathrm{pH}$ or conductivity change. Whereas at neutral $\mathrm{pH}$, bicarbonate ions are formed and it is difficult to form carbonates with divalent ions. In this situation, it is difficult to form precipitation.

Fig. 6 (a) shows observations of conductivity at the liquid level of $50 \mathrm{~cm}$ by installing two points or probes at a height of $25 \mathrm{~cm}$ and 45 $\mathrm{cm}$. It can be seen that at the liquid level of $50 \mathrm{~cm}$, the formation of the maximum PCC occurs approximately 20 minutes which is indicated by high conductivity. At the initial stage, at a height of 25 $\mathrm{cm}$, there is still high conductivity compared to the height of $45 \mathrm{~cm}$. However, at a height of $25 \mathrm{~cm}$ and $45 \mathrm{~cm}$, it has the same tendency in the second stage where there is a decrease in conductivity to a constant.

Next,Fig. 6 (b) shows observations of conductivity at the liquid level $65 \mathrm{~cm}$ by installing two points or probes at a height of $25 \mathrm{~cm}$ and $60 \mathrm{~cm}$. It can be seen that at the liquid level of $60 \mathrm{~cm}$, the formation of the maximum PCC occurs a little longer than the liquid level $50 \mathrm{~cm}$. Then, this is followed by the second stage which is a decrease in the value of conductivity to a constant.

In Fig. 6 (c), observations of conductivity at the liquid level $80 \mathrm{~cm}$ by installing two points or probes at a height of $25 \mathrm{~cm}$ and $75 \mathrm{~cm}$ are presented. At a height of $25 \mathrm{~cm}$, it has the same tendency as before, which is a decrease in conductivity value after 20 minutes. At this height, $\mathrm{pH}$ decreases after the $20^{\text {th }}$ minute which is marked by a decrease in the conductivity value. It can be seen at a liquid level of $80 \mathrm{~cm}$, the formation of the maximum PCC occurs longer at a height of $75 \mathrm{~cm}$ compared to the previous one which is more than 20 minutes. In the second stage, we can see a decrease in the value of conductivity to a constant, indicating thatthe higher the level of liquid, the more maximum the PCC is formed but at a certain high limit. Maintaining $\mathrm{pH}>10$ is the most important key to ensure that the process of absorption and formation of precipitation runs optimally. By increasing the initial level of liquid at the liquid level limit, the time needed to form PCC in the first stage is much longer to allow the $\mathrm{CO}_{2}$ absorption process to run maximally. 


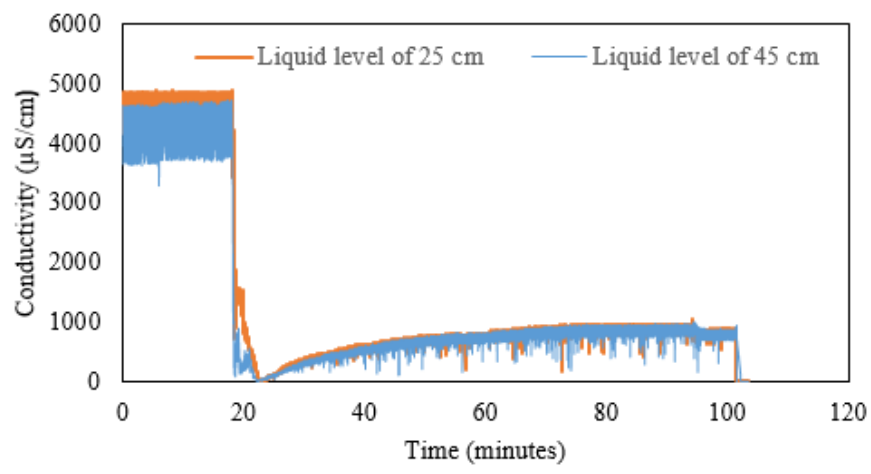

(a)

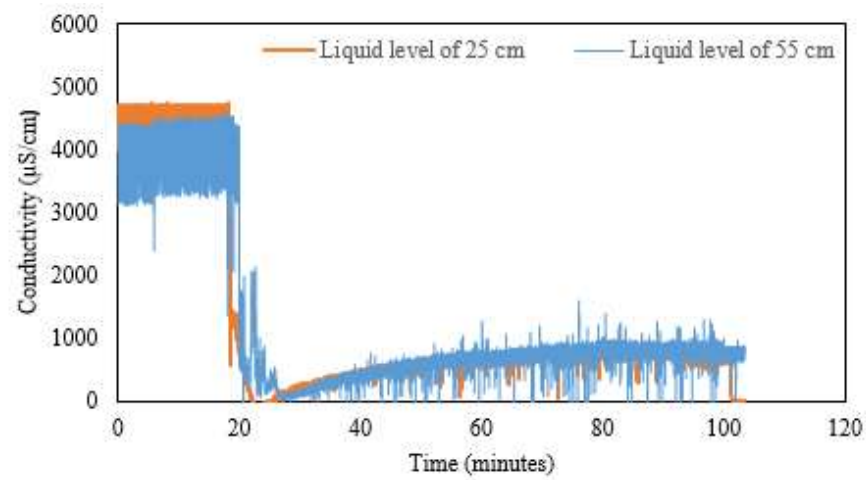

(b)

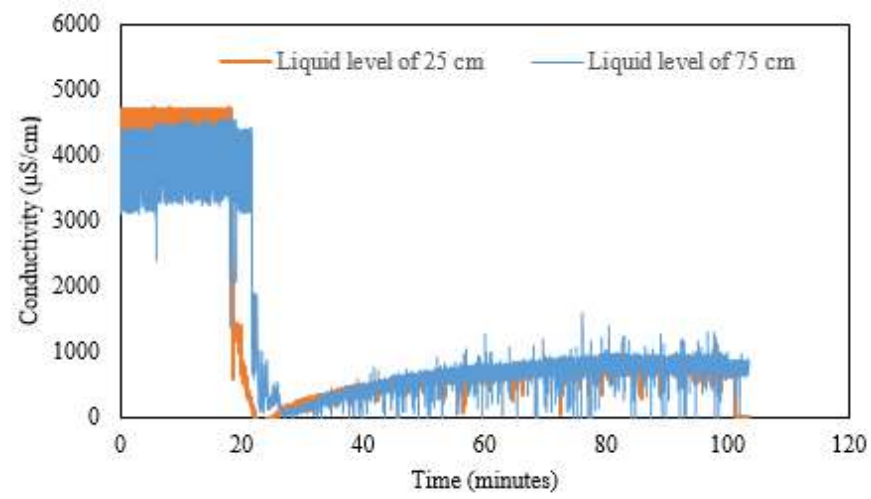

(c)

Fig. 6 Conductivity at different levels of liquid (a) $50 \mathrm{~cm}$ (b) $65 \mathrm{~cm}$ and (c) $80 \mathrm{~cm}$.

\section{Characteristic of Particle}

As shown in Fig. 7, from several PCC samples, characterization of crystallinity with X-ray or XRD (Xray Diffraction) was performed. XRD pattern in Fig. 7 shows the presence of peaks at $2 \Theta=23.1,29.4$, $34.2,36,39.5,43.2,47.6,48.6,57.6,60.9$, and 64.9. The peaks show the calcite phase in calcium carbonate formed in the carbonate process.

Data on X-ray fluorescence were taken on a precipitated calcium carbonate (PCC) sample obtained from the reaction between a solution of $\mathrm{Ca}(\mathrm{OH})_{2}$ with pure $\mathrm{CO}_{2}$. The composition of calcium carbonate produced in this process is shown in Table 3.

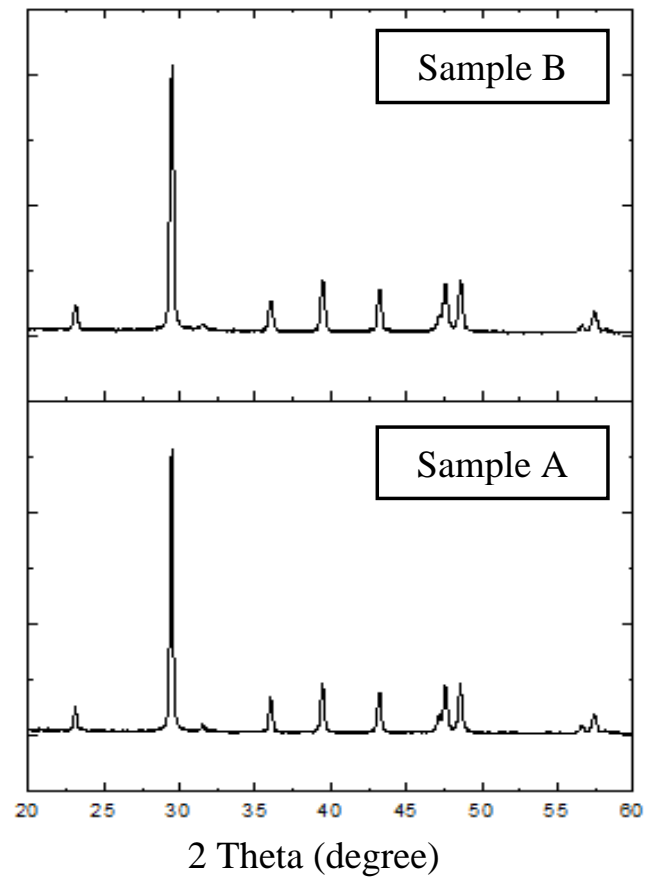

Figure 7 Results of PCC XRD analysis (Sample A: calcite phase with the use of biogas; Sample B: calcite phase with the use of pure $\mathrm{CO}_{2}$ ).

Table 3 Composition elements in PCC using (X-ray fluorescence).

\begin{tabular}{cc}
\hline Elements & Composition (\%) \\
\hline $\mathrm{Ca}$ & 99.43 \\
$\mathrm{Fe}$ & 0.36 \\
$\mathrm{Cu}$ & 0.09 \\
$\mathrm{Zn}$ & 0.02 \\
$\mathrm{Sr}$ & 0.05 \\
$\mathrm{Mo}$ & 0.02 \\
$\mathrm{Ra}$ & 0.04 \\
Total & 100 \\
\hline
\end{tabular}

Based on the results of the morphological analysis using SEM as illustrated in Fig. 8, it shows that the calcite phase which is rhombohedral or cube is dominantly formed. The PCC size obtained from the image analysis software is between $225-270 \mathrm{~nm}$.

The use of $\mathrm{CO}_{2}$ contained in biogas and pure $\mathrm{CO}_{2}$ in the absorption process has no effect on the crystalline phase and morphology of calcite formed. In another study, it was stated that the morphology of calcite was strongly influenced by the absorbent concentration used. Calcite with the seed-like prismatic and scalenohedron form is dominantly formed by the presence of high absorbent concentrations (Jimoh et al., 2017). Changing the properties of $\mathrm{CO}_{2}$ sources using biogas will affect the density and viscosity of the gas. Biogas has a higher density than pure $\mathrm{CO}_{2}$. The higher the density of the gas will change the properties of bubbles such as bubble size. This smaller bubble size will cause a greater gas hold up (Bang et al., 2015). The bigger the gas hold up the more gas is trapped in the solution so that it will increase the solubility of the gas. The use of biogas as a source of $\mathrm{CO}_{2}$ will only affect the increase in solubility of 


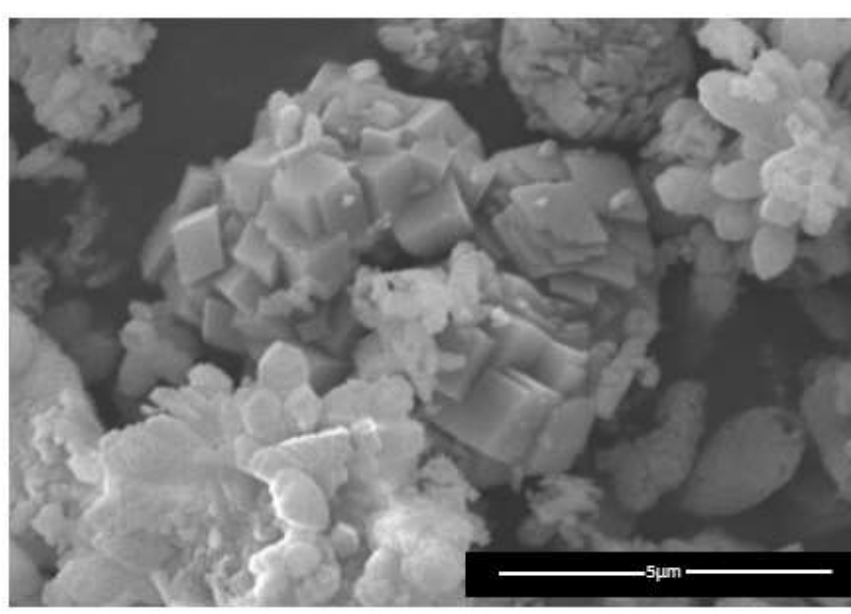

(a)

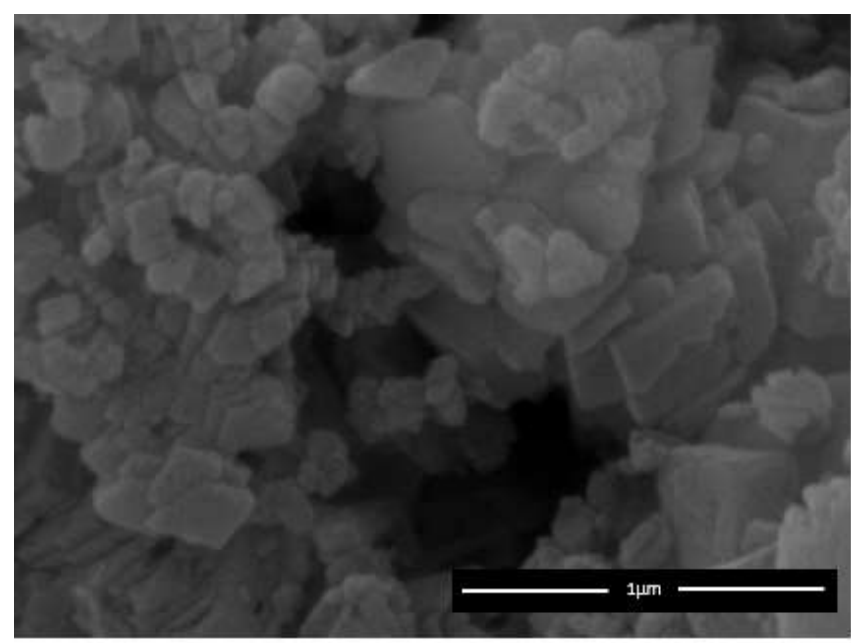

(b)

Figure 8. (a) SEM image of PCC generated from biogas (b) SEM image of PCC generated from pure of $\mathrm{CO}_{2}$

\section{CONCLUSION}

The carbonation process using a bubble column was successfully performed to purify biogas and synthesize $\mathrm{CaCO}_{3}$ nanoparticles simultaneously. The absorption of $\mathrm{CO}_{2}$ increases as the absorbent flow rate fluctuates and the gas flow rate increases. The use of absorbent above the solubility shown in the continuous process shows higher absorption of $\mathrm{CO}_{2}$. However, the upward trend of $\mathrm{CO}_{2}$ absorption is not noteworthy with increasing concentration. The highest absorption of $\mathrm{CO}_{2}$ obtained in the continuous process is 79.34 $\%$. Overall, the crystalline phase formed in this study is calcite with rhombohedral shape and has a particle size between $225-270 \mathrm{~nm}$. The use of $\mathrm{CO}_{2}$ contained in biogas and pure $\mathrm{CO}_{2}$ in the absorption process has no effect on the crystalline phase and morphology of calcite formed.

\section{ACKNOWLEDGEMENT}

The authors gratefully acknowledged the partial financial support provided by The Research-Based Community Services grant from LPPM ITS.

\section{REFERENCES}

Mamun, M. R., Al, Karim, M. R., Rahman, M. M., Asiri, A. M., Torii, S. 2015. Methane enrichment of biogas by carbon dioxide fixation with calcium hydroxide and activated carbon. Journal of the Taiwan Institute of Chemical Engineers. 0, 1-6.

Niesner, J., Jecha, D., Stehlik, P. 2013. Biogas upgrading technologies: State of art review in European region. Chemical Engineering Transactions. 35, 517-522.

Han Sang, J., Yoo, M., Kim Dong, W., Wee Jung, H. 2011. Carbon dioxide capture using calcium hydroxide aqueous solution as the absorbent. Energy Fuels. 25, 3825-3834.

De Crom, K., Chiang, Y. W., Gerven, T. V., Santos, R. M. 2015. Purification of slag-derived leachate and selective carbonation for high-quality precipitated calcium carbonate synthesis. Chemical Engineering Research and Design. 104, 180-190.

Ihsana, Y., Bonif, H., Makarim, F., Kusdianto, Winardi, S., Soewarno, N. 2017. Purification of biogas into biomethane and precipitated calcium carbonate (PCC) using bubble column of lime water. Conference on Innovation and Industrial Application (CINIA). November 29, Surabaya.

Yincheng, G., Zhenqi, N., Wenyi, L. 2011. Comparison of removal efficiencies of carbon dioxide between aqueous ammonia and $\mathrm{NaOH}$ solution in a fine spray column. Energy Procedia. 4, 512-518.

Xi, L., Jun, Z., Xiaoning, L., Yilu, C., Xiaoyu, Y., Shuya, W., Tao, Z., Haoran, Y. 2015. Continuous process of biogas purification and co-production of nano calcium carbonate in multistage membrane reactors. Chemical Engineering Journal. 271, 223-231.

Tippayawong, N., Thanompongchart, P. 2010. Biogas quality upgrade by simultaneous removal of $\mathrm{CO}_{2}$ and $\mathrm{H}_{2} \mathrm{~S}$ in a packed column reactor. Energy. 35, 4531-4535.

De Guido, G., Pellegrini Laura, A., Besagni, G., Inzoli, F. 2017. Acid gas removal from natural gas by water washing. Chemical Engineering Transactions. 57, 1129-1134.

Hayashi, Y., Hirai, E., Shimizu, N. 1975. Journal of Chemical Engineering of Japan. 812, 198-202.

Van Baten, J. M., Krishna, R. 2004. CFD Modelling of bubble column reactor including of gas contraction. Chemical Engineering and Technology. 27, 1302-1308.

Bang Jung, H., Song, K., Park, S., Jeon Wan, C., Lee Seung, W., Kim, W. 2015. Effects of $\mathrm{CO}_{2}$ bubble size, $\mathrm{CO}_{2}$ flow rate and calcium source on the size and specific surface area of $\mathrm{CaCO}_{3}$ particles. Energies. 8, 12304-12313.

Jimoh, A. O., Otitoju, T. A., Hussin, H., Ariffin K. S., Baharun, N. 2017. Understanding the precipitated calcium carbonate (PCC) production mechanism and its characteritics in the liquid-gas system using milk of lime (MOL) suspension. South African Journal of Chemistry. 70, 1-7.

Bang, J.-H., Jang, Y. N., Kim, W., Song, K. S., Jeon, C. W., Chae, S. C.,Lee, M. G. 2011. Precipitation of calcium carbonate by carbon dioxide microbubbles. Chemical Engineering Journal. 174(1), 413-420. 